\title{
AKTIVITAS ANTIOKSIDAN, SITOTOKSISITAS DAN KANDUNGAN FUKOSANTIN EKSTRAK RUMPUT LAUT COKLAT DARI PANTAI BINUANGEUN, BANTEN
}

\author{
Antioxidant Activity, Cytotoxicity and Fucoxanthin content \\ of Brown Algae Extract Collected from Binuangeun Coast, Banten
}

\author{
Muhammad Nursid $^{1 *}$, Thamrin Wikanta ${ }^{1}$, dan Rini Susilowati ${ }^{1}$ \\ ${ }^{1}$ Balai Besar Penelitian dan Pengembangan Pengolahan Produk dan Bioteknologi Kelautan dan Perikanan, KKP. \\ JI. K.S. Tubun Petamburan VI, Jakarta Pusat 10260 \\ *Korespondensi Penulis: muhammadnursid@gmail.com
}

Diterima: 20 Agustus 2012, Disetujui: 24 Mei 2013

\begin{abstract}
ABSTRAK
Penelitian ini bertujuan untuk mengetahui aktivitas antioksidan, sitotoksisitas dan kandungan fukosantin ekstrak etil asetat beberapa jenis rumput laut coklat. Aktivitas antioksidan dianalisis dengan menggunakan metode 2,2-Diphenyl-1-Picrylhydrazyl (DPPH) sedangkan aktivitas sitotoksik diuji dengan menggunakan metode \{3-(4,5-dimethylthiazol-2-yl)-2,5-diphenyl-tetrazolium bromide\} (MTT). Kadar fukosantin dianalisis menggunakan metode Kromatografi Cair Kinerja Tinggi (KCKT). Enam jenis rumput laut coklat yaitu Sargassum ilicifolium, Sargassum binderi, Turbinaria decurrens, Turbinaria ornata, Padina australis dan Hormophysa triquetra telah dikoleksi dari pantai Binuangeun, Propinsi Banten. Ekstrak P. australis menunjukkan aktivitas antioksidan yang paling tinggi diiikuti oleh $H$. triquetra dan $T$. decurrens. Hasil uji memperlihatkan bahwa ekstrak T. decurrens menghambat pertumbuhan sel HeLa dan T47D sedangkan $H$. triquetra hanya menghambat pertumbuhan sel T47D. Kadar fukosantin tertinggi dihasilkan oleh ekstrak H. triquetra sebesar $88,5 \mathrm{mg} / \mathrm{g}$ diikuti oleh $T$. decurrens, dan $P$. australis, berturut-turut sebesar $86,9 \mathrm{mg} / \mathrm{g}$, dan $77,8 \mathrm{mg} / \mathrm{g}$. Di lain sisi, kandungan fukosantin ekstrak S. ilicifolium, T. ornata, dan S. binderi relatif rendah (<20 ppm).
\end{abstract}

KATAKUNCl: antioksidan, sitotoksisitas, fukosantin, rumput laut coklat

\section{ABSTRACT}

The research was aimed to investigate antioxidant and cytotoxic activities of ethyl acetate extract of several brown algae species and its fucoxanthin content. Antioxidant activity was evaluated by using 2,2-Diphenyl-1-Picrylhydrazyl (DPPH) assay while cytotoxic activity was determined by using \{3-(4,5-dimethylthiazol-2-yl)-2,5-diphenyl-tetrazolium bromide\} (MTT) assay. Fucoxanthin content was analyzed by using High Performance Liquid Chromatography method. Six species of brown algae, i.e Sargassum ilicifolium, Sargassum binderi, Turbinaria decurrens, Turbinaria ornata, Padina australis and Hormophysa triquetra were collected from the Binuangeun coast, Banten Province. P. australis extract exhibited the highest antioxidant activity followed by H.triquetra and T.decurrens. The MTT test showed that T. decurrens extract inhibited the growth of HeLa and T47D cells while $\boldsymbol{H}$. triquetra only inhibited the growth of T47D cells. The highest fucoxanthin content of $\boldsymbol{H}$. triquetra extract was $88.5 \mathrm{mg} / \mathrm{g} \mathrm{ppm}$ followed by $\boldsymbol{T}$. decurrens and $\boldsymbol{P}$. australis with concentration of $86.9 \mathrm{mg} / \mathrm{g}$ and $77.8 \mathrm{mg} / \mathrm{g}$, respectively. In the other hand, the fucoxanthin content of S. ilicifolium, S. binderi and T. ornata extracts were low (<20 ppm).

KEYWORDS: antioxidant, cytotoxicity, fucoxanthin, brown algae

\section{PENDAHULUAN}

Garis pantai Indonesia mencapai sekitar 95.181 km (Anon., 2012) yang ditumbuhi oleh beragam jenis rumput laut. Gupta \& Abu-Ghannam, 2011 menyatakan bahwa rumput laut dibagi menjadi 3 kelompok besar berdasarkan komposisi kimianya yaitu alga hijau (Chlorophyta), alga merah (Rhodophyta), dan alga coklat (Phaeophyta). Rumput laut mengandung senyawa aktif dengan berbagai bioaktivitas sehingga memiliki potensi untuk dikembangkan sebagai bahan nutraseutikal (Kelman et al., 2012). Rumput laut coklat 
merupakan sumber dari metabolit yang bernilai ekonomi seperti karotenoid, laminarin, alginat, fukoidan, manitol, dan phlorotanin (Demirel et al., 2012; Jaswir et al., 2012).

Rumput laut coklat diperkirakan melimpah di sepanjang garis pantai tersebut. Salah satu lokasi alga coklat yang melimpah di wilayah Indonesia adalah pantai Binuangeun, Kabupaten Lebak, Banten. Menurut penelitian Kusumawati et al. (2012), sekurang-kurangnya terdapat 6 jenis rumput laut coklat di pantai Binuangeun. Rumput laut coklat lebih dikenal sebagai penghasil alginat dan iodin. Kandungan pigmen pada thalli didominasi oleh khlorofil a, c, beta karoten, violasantin, dan fukosantin (Kadi, 2004). Beberapa laporan mengenai penelitian bioprospeksi rumput laut coklat yang berasal dari Binuangeun misalnya dilaporkan oleh Nursid et al. (2007) dan Fajarningsih et al. (2008). Kedua penelitian tersebut mengkaji potensi alga coklat Turbinaria decurrens sebagai bahan anti kanker. Namun sejauh ini laporan tentang bioprospeksi alga coklat dari jenis lain dari wilayah ini masih terbatas.

Karotenoid merupakan kelompok pigmen penting yang dihasilkan oleh biota laut. Salah satu pigmen dari golongan karotenoid yang banyak dihasilkan oleh alga coklat adalah fukosantin. Fukosantin banyak ditemukan dalam lingkungan laut, mencakup sekitar 10\% dari total produksi karoten di lautan (Peng et al., 2011). Fukosantin menarik perhatian para peneliti karena bioaktivitasnya yang sangat baik seperti antioksidan (Nomura et al., 1997), antikanker (Yoshiko \& Hoyuku, 2007), anti sinar ultra violet (Urikura et al., 2011) dan lain-lain. Fukosantin dari alga coklat berpotensi untuk dikembangkan sebagai bahan nutraseutikal terutama sebagai antioksidan dan agen kemopreventif karena kemampuannya dalam meredam radikal bebas. Berdasarkan hal tersebut maka penelitian untuk mengetahui potensi rumput laut coklat sebagai bahan nutraseutikal dari perairan Indonesia khususnya dari pantai Binuangeun-Banten perlu dilakukan.

Penelitian ini bertujuan untuk mengetahui aktivitas antioksidan dan anti kanker serta kandungan fukosantin beberapa spesies rumput laut coklat dari pantai Binuangen, Banten.

\section{METODE}

\section{Pengambilan Sampel dan Identifikasi Rumput Laut}

Sampel diambil dari Pantai Binuangeun, Kabupaten Lebak, Banten, pada bulan Mei 2013. Sampel rumput laut diambil sebanyak $1 \mathrm{~kg}$ dari beberapa titik pada zona pasang surut di sepanjang pantai Binuangeun. Sampel segar yang diperoleh segera dicuci dengan air tawar dan langsung dimaserasi dengan metanol pro analisa (p.a) dan disimpan dalam kotak pendingin yang berisi es batu. Sesampainya di laboratorium, sampel disimpan dalam pendingin (freezer) bersuhu $-20^{\circ} \mathrm{C}$ sebelum dianalisis. Jenis rumput laut coklat hasil sampling diidentifikasi di Pusat Penelitian Oseanografi Lembaga IImu Pengetahuan Indonesia (P2O LIPI).

\section{Ekstraksi Rumput Laut}

Ekstraksi dilakukan dengan metanol p.a, kemudian ekstrak yang diperoleh dievaporasi dengan rotavapor vakum sampai metanol habis menguap. Ekstrak kental yang mengandung air selanjutnya ditambahkan dengan $50 \mathrm{ml}$ etil asetat, lalu dimasukkan ke dalam corong pisah, dikocok selama lebih kurang 2 menit, didiamkan beberapa saat hingga terbentuk 2 bagian. Bagian atas dari campuran (fraksi etil asetat) dipisahkan dan segera dievaporasi, sedangkan bagian bawah (fraksi air) ditampung di tempat terpisah. Seluruh kegiatan ekstraksi dan partisi dilakukan di ruang gelap. Bioaktivitas ekstrak etil asetat diuji nya sebagai antioksidan dan antitumor melalui uji sitotoksisitas.

\section{Uji Antioksidan}

Uji antioksidan dilakukan terhadap ekstrak etil asetat karena pada ekstrak ini terkandung senyawa fukosantin yang menjadi target dalam penelitian ini. Uji antioksidan dilakukan dengan metode 1,1-difenil2-pikrilhidrazil (DPPH) (Merck) menurut Li et al. (2006) dan Nursid et al. (2008). Dosis ekstrak yang digunakan dalam penelitian ini sebesar $50 \mu \mathrm{g} / \mathrm{ml}$ dengan waktu inkubasi 30 menit. Vitamin C digunakan sebagai kontrol positif tetapi dengan dosis yang lebih rendah dari perlakuan ekstrak sampel yaitu sebesar $10 \mu \mathrm{g} / \mathrm{ml}$.

\section{Uji Sitotoksisitas}

Uji sitotoksisitas dilakukan dengan metode MTT (3-(4,4-dimethylthiazol-2-yl)-2,5-diphenyl-tetrazolium bromide) menggunakan sel lestari HeLa dan T47D menurut Freshney (2005) dengan beberapa modifikasi. Sel dikultur dalam medium Roswell Park Memorial Institut 1640 (RPMI) (Sigma) yang ditambah dengan Fetal Bovine Serum (FBS) 10\% (Gibco), fungison 0,5\% (Gibco), dan penisilin-streptomisin 2\% (Gibco). Sel dipelihara dalam inkubator dengan aliran $\mathrm{CO}_{2}$ sebesar $5 \mathrm{ml} / \mathrm{menit}$ pada suhu $37^{\circ} \mathrm{C}$. Jumlah sel yang digunakan dalam uji sebesar $1,5 \times 10^{4}$ sel/sumuran. Dosis ekstrak yang digunakan sebesar $30 \mu \mathrm{g} / \mathrm{ml}$. Dalam uji ini digunakan doksorubisin pada dosis 5 $\mu \mathrm{g} / \mathrm{ml}$ sebagai kontrol positif. Doksorubisin merupakan salah satu obat kemoterapi yang tersedia secara 
komersial di pasaran. Persentase kematian sel tumor dihitung berdasarkan rumus $[\{(A-D)-(B-C)\} /(A-D)] x$ $100 \%$ dimana $\mathrm{A}=$ absorbansi kontrol sel, $\mathrm{B}=$ absorbansi sampel, $\mathrm{C}=$ absorbansi kontrol sampel dan $\mathrm{D}=$ absorbansi kontrol media.

\section{Analisis Kandungan Fukosantin}

Kandungan fukosantin dalam ekstrak etil asetat rumput laut coklat dianalisis dengan menggunakan kromatografi cair kinerja tinggi (KCKT). Kadar fukosantin dinyatakan dalam satuan mg per 1 gram ekstrak etil asetat. Identifikasi fukosantin dilakukan dengan membandingkannya dengan standar fukosantin (Sigma-Aldrich) berdasarkan waktu retensi (Rt) dan kromatogram ultra violet (UV) fukosantin. Konsentrasi fukosantin dihitung berdasarkan luas puncak (peak area) kromatogram fukosantin ekstrak etil asetat dengan menggunakan persamaan garis regresi linier yang dihasilkan oleh standar fukosantin. Sebanyak $1 \mathrm{mg}$ ekstrak etil asetat rumput laut dilarutkan dalam $1 \mathrm{ml}$ metanol sehingga konsentrasinya menjadi 1000 ppm. Pengukuran kadar fukosantin dalam penelitian ini menggunakan 3 kali ulangan. Kondisi KCKT yang digunakan adalah sebagai berikut: instrumen Shimadzu LC-10AD, detektor Diode Array Detector (SPD-M20A Shimadzu), fase diam $C_{18}$ Zorpax 150 x 2,0 mm, fase gerak gradien asetonitril terhadap air 10-100\%, laju alir 0,2 $\mathrm{ml} /$ menit, dan volume injeksi 10 ì l. Hubungan antara kandungan fukosantin dengan aktivitas antioksidan dan sitotoksisitas diuji dengan analisis korelasi Pearson.

Tabel 1. Hasil identifikasi beberapa jenis rumput laut coklat dari pantai Binuangeun, Banten Table 1. Identification result of several brown algae specieses from Binuangeun coast, Banten

\begin{tabular}{|c|c|c|c|}
\hline No & & KodelCode & Hasil Identifikasil/dentification Result \\
\hline 1 & RL01 & & $\begin{array}{l}\text { Kelas/class : Phaeophyceae } \\
\text { Bangsa/order: Fucales } \\
\text { Suku/family : Sargassaceae } \\
\text { Marga/genus : Sargassum } \\
\text { Jenis/species : Sargassum ilicifolium }\end{array}$ \\
\hline 2 & RL06 & & $\begin{array}{l}\text { Kelas/class : Phaeophyceae } \\
\text { Bangsa/order : Fucales } \\
\text { Suku/family : Sargassaceae } \\
\text { Marga/genus : Sargassum } \\
\text { Jenis/species : Sargassum binderi }\end{array}$ \\
\hline 3 & RL14 & & $\begin{array}{l}\text { Kelas/class : Phaeophyceae } \\
\text { Bangsa/order : Fucales } \\
\text { Suku/family : Sargassaceae } \\
\text { Marga/genus : Turbinaria } \\
\text { Jenis/species : Turbinaria decurrens }\end{array}$ \\
\hline 4 & RL15 & & $\begin{array}{l}\text { Kelas/class : Phaeophyceae } \\
\text { Bangsa/order: Fucales } \\
\text { Suku/family : Sargassaceae } \\
\text { Marga/genus : Turbinaria } \\
\text { Jenis/species : Turbinaria ornata }\end{array}$ \\
\hline 5 & RL02 & & $\begin{array}{l}\text { Kelas/class : Phaeophyceae } \\
\text { Bangsa/order : Dictyotales } \\
\text { Suku/family : Dictyoceae } \\
\text { Marga/genus : Padina } \\
\text { Jenis/species : Padina australis }\end{array}$ \\
\hline 6 & RL07 & & $\begin{array}{l}\text { Kelas/class : Phaeophyceae } \\
\text { Bangsa/order: Scytosiphonales } \\
\text { Suku/family : Cystoceiraceae } \\
\text { Marga/genus : Hormophysa } \\
\text { Jenis/species : Hormophysa triquetra }\end{array}$ \\
\hline
\end{tabular}




\section{HASIL DAN BAHASAN}

\section{Identifikasi Rumput Laut}

Hasil identifasi rumput laut coklat yang dilakukan di P2O LIPI memperlihatkan bahwa 6 sampel yang diteliti terdiri dari 4 genus yaitu Sargassum, Turbinaria, Padina, dan Hormophysa (Tabel 1).

\section{Aktivitas Antioksidan}

Jenis rumput laut coklat yang memiliki aktivitas antioksidan paling kuat adalah $P$. australis dengan nilai hambatan terhadap radikal bebas DPPH sebesar $53 \%$ pada dosis $50 \mu \mathrm{g} / \mathrm{ml}$ dan waktu inkubasi 30 menit diikuti oleh $H$. triquetra (45\%) dan $T$. decurrens (33\%). Asam askorbat atau vitamin C sebagai kontrol positif memiliki hambatan sebesar $92 \%$ pada dosis $10 \mu \mathrm{g} /$ $\mathrm{ml}$ (Gambar 1). Rumput laut coklat S. ilicifolium, S. binderi, dan $T$. ornata memiliki aktivitas peredaman radikal bebas yang relatif kecil bahkan di bawah $10 \%$ untuk S. ilicifolium dan S. binderi.

Radikal bebas adalah atom atau molekul yang mengandung satu atau lebih elektron tidak berpasangan (Buettner, 2009). Untuk menjadi stabil, radikal memerlukan elektron dari molekul donor ke molekul radikal agar radikal tersebut menjadi stabil. Akibat reaksi tersebut, molekul donor menjadi radikal baru yang tidak stabil dan memerlukan elektron dari molekul di sekitarnya untuk menjadi stabil, demikian seterusnya sehingga terjadi reaksi berantai perpindahan elektron-elektron (Windono, 2001).
Reaksi uji antioksidan menggunakan metode DPPH didasarkan pada prinsip reaksi penangkapan hidrogen dari antioksidan oleh radikal bebas DPPH. Antioksidan akan mendonorkan proton atau hidrogen kepada DPPH dan selanjutnya akan memecah rantai radikal bebas hingga membentuk senyawa yang tidak radikal (Fung, 2012).

Rumput laut yang hidup di perairan yang dangkal misalnya pantai dan zona intertidal umumnya terpapar oleh sinar matahari yang mengandung sinar UV maupun oleh udara yang banyak mengandung oksigen. Paparan sinar matahari dan udara dapat menyebabkan terbentuknya radikal bebas ataupun spesies oksigen reaktif lainnya (reactive oxygen species/ROS). Radikal bebas atau ROS akan menyebabkan oksidasi biomolekul di dalam sel sehingga menyebabkan kematian sel dan kerusakan jaringan. Namun, meskipun rumput laut terpapar ROS yang berbahaya, komponen struktural rumput laut (misalnya asam-asam lemak) tidak akan mengalami kerusakan oksidatif. Hal ini menunjukkan adanya sistem perlindungan terhadap stres oksidatif dalam sel-sel rumput laut. Dengan mendonasikan sebuah elektron, senyawa antioksidan dapat menetralkan kehadiran radikal bebas ataupun ROS (Halliwell, 1999; Mallick \& Mohn, 2000; Kelman et al., 2012). Kemampuan rumput laut dalam mensintesis senyawa antioksidan sebagai suatu sistem pertahanan dari paparan radikal bebas merefleksikan kemampuan adaptasi rumput laut terhadap radiasi sinar matahari (Budhiyanti et al., 2012).

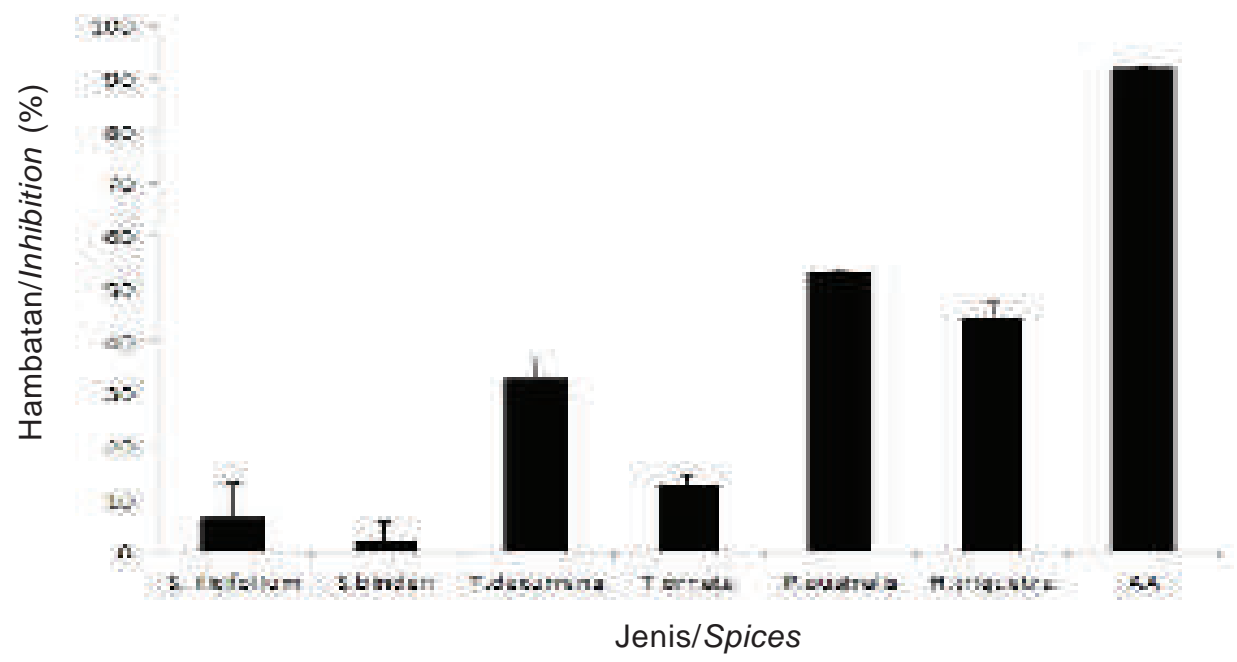

Keterangan/Note: dosis ekstrak $50 \mu \mathrm{g} / \mathrm{ml}$, dosis asam askorbat $10 \mu \mathrm{g} / \mathrm{ml}$

Gambar 1. Aktivitas antioksidan beberapa jenis rumput laut coklat dari pantai Binuangeun, Banten dan asam askorbat (AA).

Figure 1. Antioxidant activity of several brown alga species from Binuangeun coast, Banten and ascorbic $\operatorname{acid}(A A)$. 


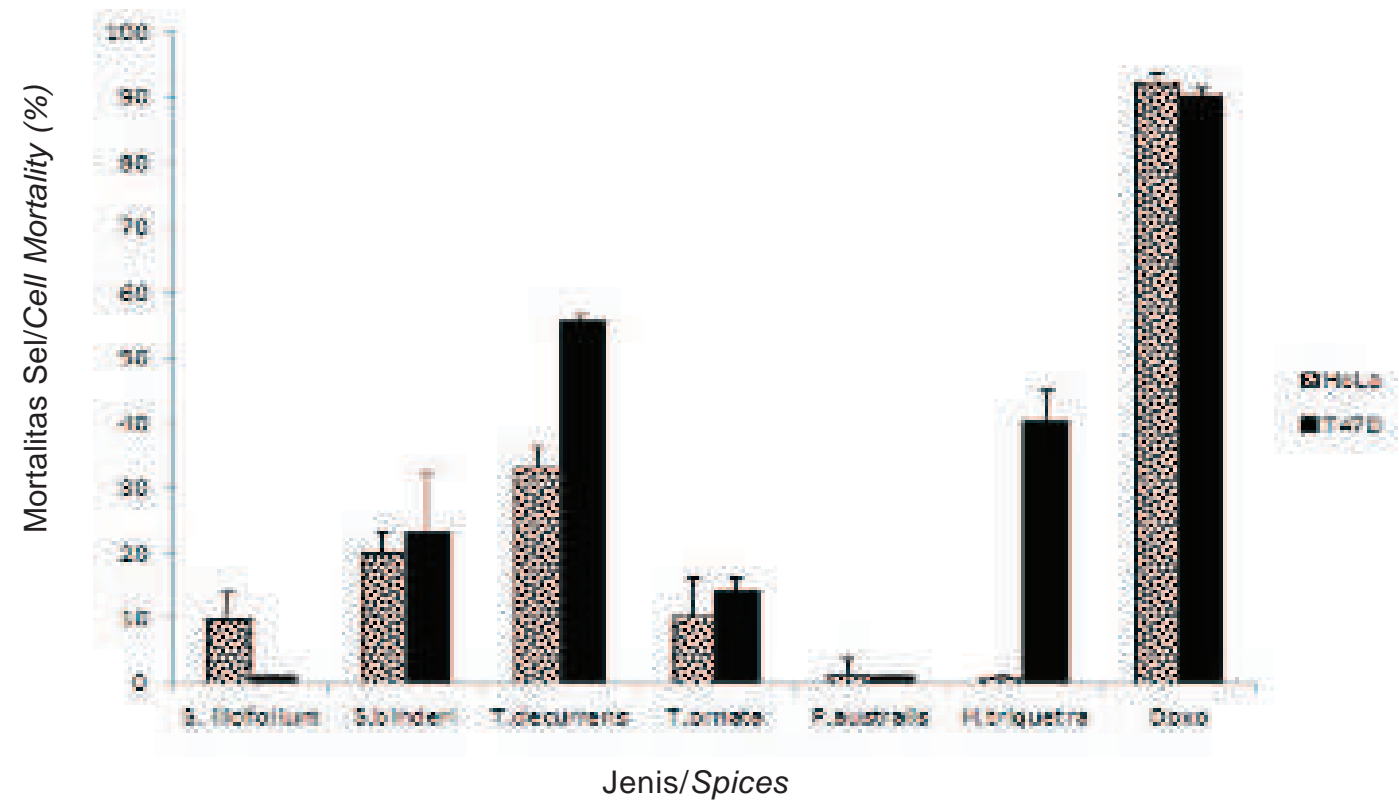

Keterangan/Note: dosis ekstrak $30 \mu \mathrm{g} / \mathrm{ml}$, dosis doksorubisin (doxo) $5 \mu \mathrm{g} / \mathrm{ml}$

Gambar 2. Aktivitas sitotoksik ekstrak rumput laut coklat terhadap sel HeLa dan T47D.

Figure 2. Cytotoxic activity of brown algae against HeLa dan T47D cells.

\section{Aktivitas Sitotoksik}

Uji aktivitas sitotoksik terhadap sel HeLa dan T47D memperlihatkan bahwa T. decurrens memiliki aktivitas sitotoksik yang paling kuat dibanding dengan rumput laut lain yang diuji, sedangkan rumput laut yang paling lemah aktivitas sitotoksiknya adalah $P$. australis. Ekstrak T. decurrens menyebabkan kematian sel T47D sebesar 56\% dan HeLa sebesar 33\% pada dosis $30 \mu \mathrm{g} / \mathrm{ml}$ (Gambar 2). Hal yang menarik adalah bahwa H. triquetra tidak memiliki aktivitas sitotoksik terhadap sel HeLa tetapi menunjukkan aktivitas sitotoksik terhadap sel T47D. Hal ini mengindikasikan bahwa ekstrak H.triquetra memiliki aktivitas sitotoksik yang spesifik terhadap sel T47D.

Efek ekstrak rumput $T$. decurrens terhadap sel HeLa dan T47D serta efek ekstrak $H$. triquetra terhadap sel T47D juga dapat dikonfirmasi secara morfologi dengan menggunakan foto sel HeLa dan T47D yang diberi perlakuan kemudian dibandingkan dengan sel tanpa perlakuan. Sel HeLa dan T47D yang terpapar ekstrak $T$. decurrens selama 24 jam terlihat berubah bentuknya bila dibandingkan dengan sel tanpa perlakuan ataupun sel yang terpapar ekstrak yang tidak aktif misalnya ekstrak S. ilifolium atau S. binderi. Suatu ekstrak yang mengandung senyawa sitotoksik dapat dengan nyata mengubah morfologi sel seperti yang terlihat pada perlakuan doksorubisin, ekstrak T. decurrens dan H. triquetra (Gambar 3).
Perubahan morfologi sel akibat paparan senyawa aktif atau agen kemoterapi tertentu merupakan refleksi dari kondisi biokimia yang dapat berujung pada kematian sel baik secara apoptosis maupun nekrosis. Apoptosis merupakan suatu proses aktif yang membutuhkan transkripsi dan translasi gen-gen spesifik tertentu dan juga memerlukan penggunaan sumber energi intraseluler. Sebaliknya nekrosis merupakan kematian sel dengan keadaan patologis. Perbedaan mekanisme yang mendasar pada kedua tipe kematian sel tersebut terefleksi pada morfologi sel-sel yang mati tersebut. Sel-sel apoptotik volume sitoplasmanya berkurang, inti sel menyusut, membran dan organel-organel tetap menyatu, sebaliknya pada sel-sel nekrotik, sel menjadi menggelembung atau bengkak, inti sel mengalami lisis, membran plasma dan membran inti rusak dan organel-organel sel mengalami desintegrasi (Martin, 2006; Elmore, 2007; Doonan \& Cotter, 2008).

Dalam penelitian ini belum diketahui kematian sel HeLa dan T47D setelah terpapar ekstrak rumput laut coklat apakah disebakan oleh apoptosis atau nekrosis. Namun aktivitas sitotoksik rumput laut coklat terhadap kedua sel tersebut diduga berhubungan dengan senyawa- fukosantin yang terkandung dalam rumput laut coklat. Menurut Mori et al. (2004), rumput laut coklat secara umum mengandung senyawa fukosantin. Fukosantin merupakan senyawa golongan karotenoid yang dapat menginduksi apoptosis pada 
A

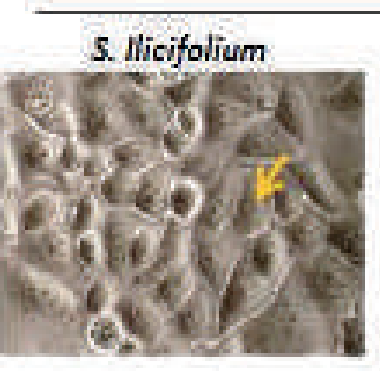

Paustralis

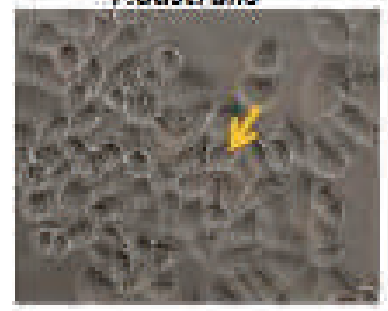

(1)

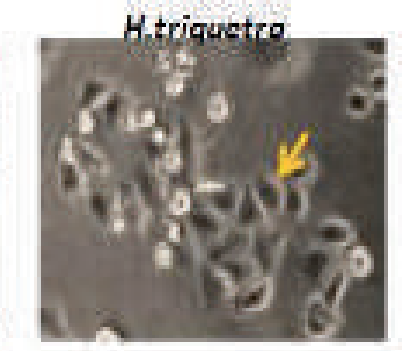

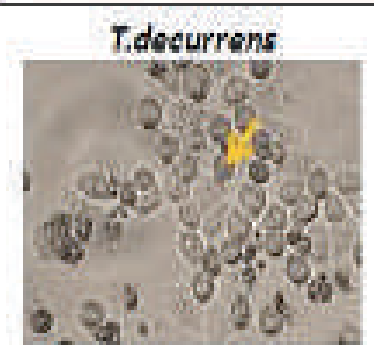
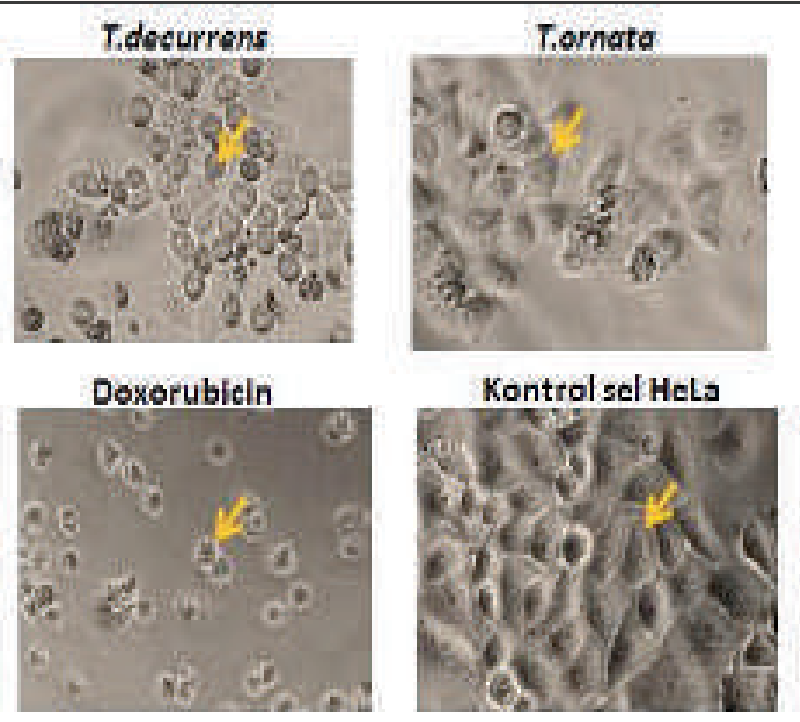

B
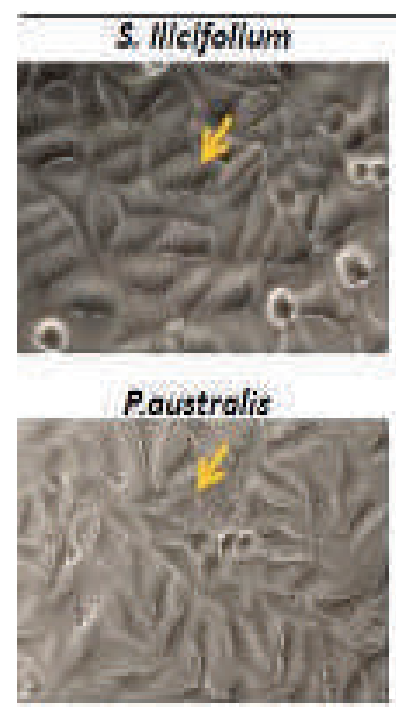
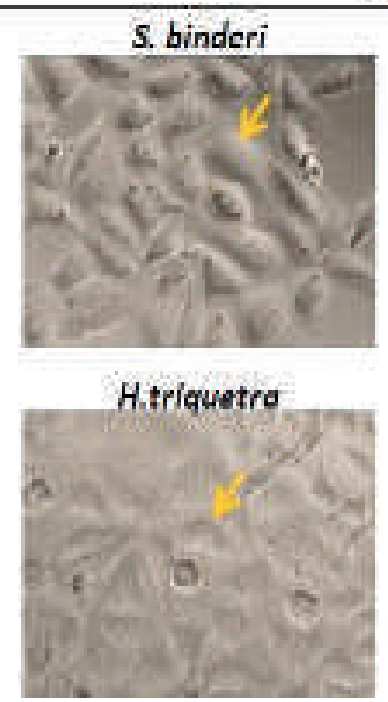
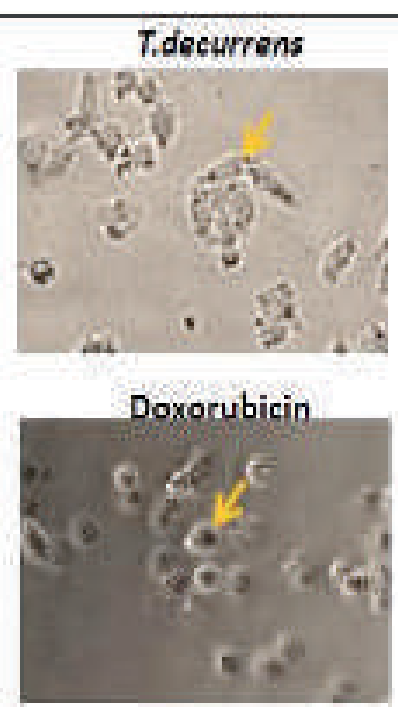

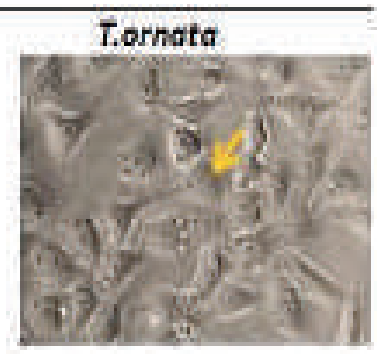

Kontrol sel T470

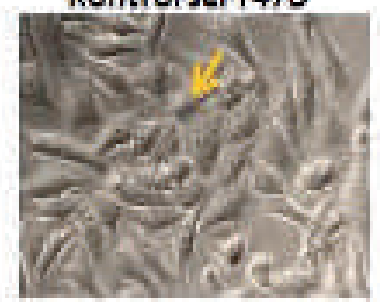

Gambar 3. Efek ekstrak rumput laut coklat $(30 \mu \mathrm{g} / \mathrm{ml})$ terhadap morfologi sel HeLa (A) dan T47D (B).

Figure 3. Effect of brown algae extract $(30 \mu \mathrm{g} / \mathrm{ml})$ on morphology of HeLa (A) and T47D cells (B).

sel. Selain karotenoid, terdapat kemungkinan bahwa senyawa-senyawa dari golongan steroid yang terdapat dalam rumput laut coklat bertanggung jawab atas aktivitas sitotoksiknya seperti yang dilaporkan oleh Sheu et al. (1999).

\section{Kandungan Fukosantin}

Berdasarkan waktu retensi standar fukosantin, puncak (peak) senyawa fukosantin terdeteksi pada menit ke 33,01. Selain itu digunakan juga spektrum UV standar fukosantin yang memiliki serapan optimum pada panjang gelombang 226, 267, dan $447 \mathrm{~nm}$.
Puncak fukosantin sangat nyata terlihat pada ekstrak T. decurrens, $P$. australis dan H. triquetra, sedangkan pada S. ilicifolium, S. binderi dan T. ornata puncak fukosantin hampir tidak terdeteksi (Gambar 4).

Hasil analisis kadar fukosantin dengan menggunakan kurva standar fukosantin, memperlihatkan bahwa $H$. triquetra, T. decurrens, dan $P$. australis memiliki kadar fukosantin yang tinggi tetapi tidak terlalu berbeda kadarnya yaitu berturutturut sebesar 88,5 per 1 gram ekstrak etil asetat (mg/ g EA), 86,9 mg/g dan 77,8 mg/g. Sebaliknya S. ilicifolium, S. binderi dan T. ornata memiliki kadar 

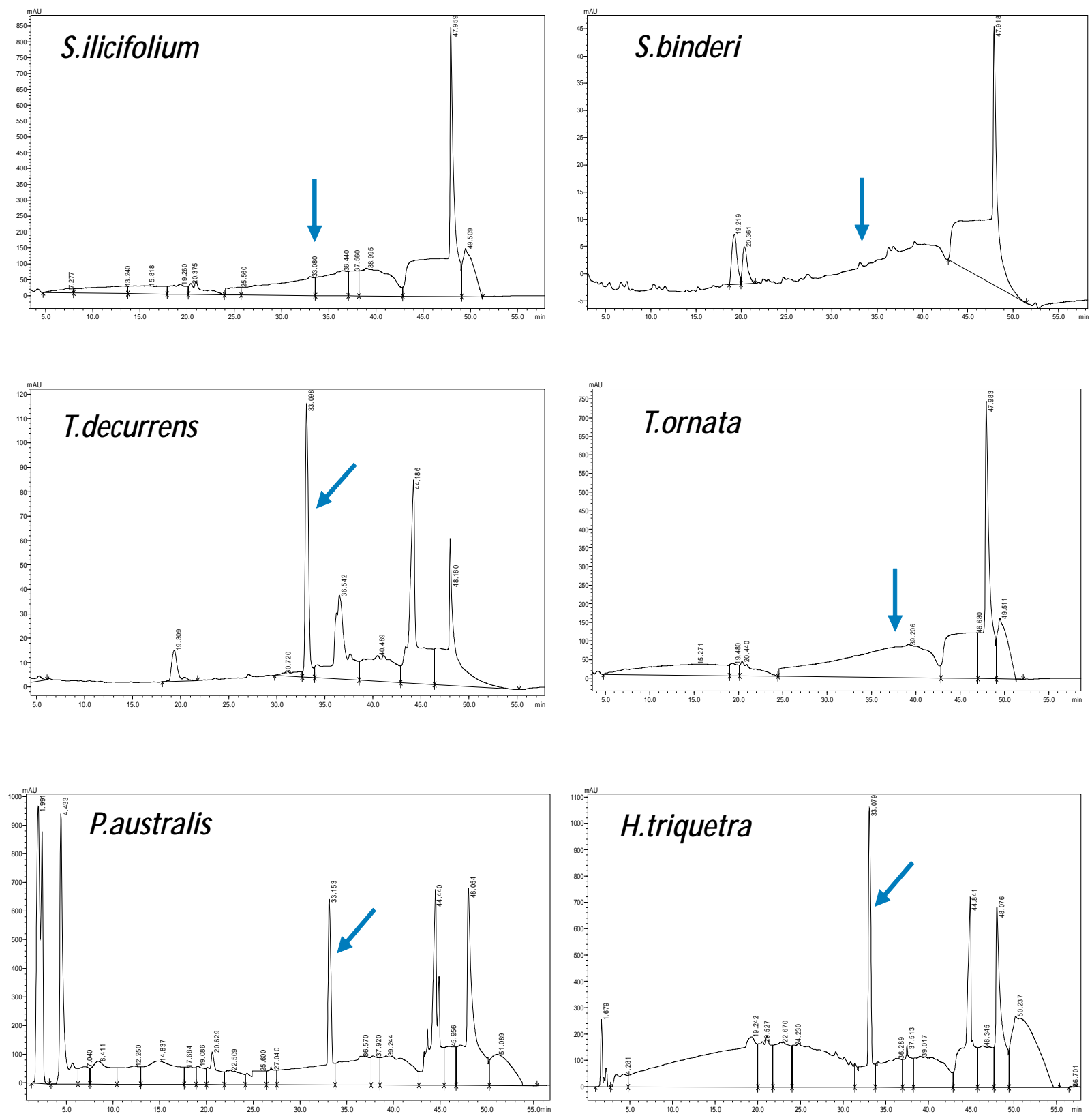

Gambar 4. Puncak senyawa fukosantin (panah) dalam ekstrak etil asetat rumput laut coklat. Figure 4. Fucoxanthin peak (arrow) of brown algae ethyl acetate extract.

fukosantin yang rendah yaitu di bawah $10 \mathrm{mg} / \mathrm{g}$. Tingginya kadar fukosantin dari $H$. triquetra, $T$. decurrens, dan $P$. australis mendukung hasil uji antioksidan ketiga jenis rumput laut coklat tersebut. Berdasarkan analisis korelasi Pearson, semakin tinggi kadar fukosantin maka aktivitas antioksidannya semakin tinggi $(p<0,05)$. Hal ini mengindikasikan bahwa fukosantin yang dihasilkan oleh ketiga rumput laut tersebut berperan sebagai perisai untuk melindungi diri dari stres oksidatif seperti tingginya intensitas sinar matahari. Hal ini sesuai dengan pendapat Gupta \& Abu-Ghannam (2011) yang menyatakan bahwa rumput laut seperti halnya tanaman fotosintesis terestrial memiliki mekanisme antioksidatif yang berperan untuk melindungi dirinya dari stres lingkungan.

Meskipun terdapat korelasi yang nyata antara kandungan fukosantin dengan aktivitas antioksidan, tetapi tingginya kandungan fukosantin tidak berkorelasi dengan aktivitas sitotoksik baik terhadap sel HeLa maupun T47D ( $p>0,05)$. Meskipun demikian, kandungan fukosantin yang tinggi pada $T$. decurrens seiring dengan tingginya aktivitas sitotoksik rumput laut tersebut terhadap sel HeLa dan T47D. Ekstrak 


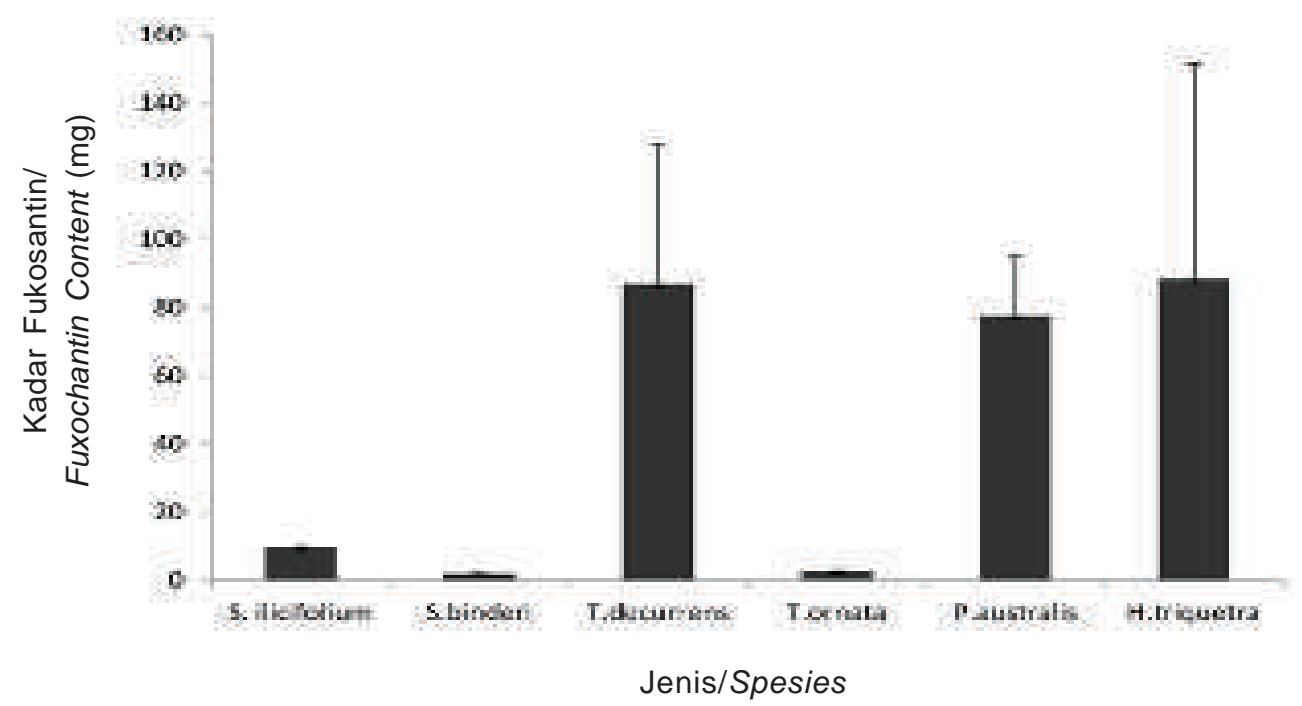

Gambar 5. Kadar fukosantin beberapa jenis rumput laut coklat dari pantai Binuangeun, Banten (per $1 \mathrm{mg}$ ekstrak etil asetat).

Figure 5. Fucoxanthin concentration of several brown algae species from Binuangeun coast, Banten (per 1 mg ethyl acetate extract).

H.triqeutra dengan kandungan fukosantin yang tinggi juga memperlihatkan aktivitas sitotoksik yang tinggi terhadap sel T47D. Khusus untuk $P$. australis, aktivitas sitotoksiknya sangat rendah meskipun kandungan fukosantin-nya tinggi. Rendahnya aktivitas sitotoksik P.australis kemungkinan disebabkan oleh fukosantin yang terkandung di dalamnya mengalami kerusakan karena fukosantin merupakah golongan pigmen yang tidak stabil. Fukosantin mudah terdegradasi oleh panas, paparan cahaya, dan $\mathrm{pH}$ yang rendah ( $\mathrm{Hi}$ et al., 2010). Hasil penelitian Jaswir et al. (2011) memperlihatkan bahwa fukosantin yang diisolasi dari $P$. australis memiliki sitotoksisitas terhadap sel H1299 (lung cancer) dengan $\mathrm{IC}_{50}$ sebesar 2,45 mM.
Aktivitas sitotoksik pada rumput laut coklat tidak selalu berhubungan dengan fukosantin karena selain fukosantin alga coklat juga mengandung senyawa aktif dari golongan lain. Sheu et al. (1999) melaporkan bahwa $T$. conoides mengandung senyawa-senyawa steroid teroksigenasi yang tergolong dalam kelompok senyawa fucosterol. Fucosterol memiliki aktivitas sitotoksik terhadap beberapa jenis sel lestari tumor. Fucosterol yang diisolasi dari rumput laut coklat Undaria pinnatifida dilaporkan memiliki aktivitas sebagai antidiabetes, antioksidan, dan antiosteoporesis (Yoo et al., 2012). Hasil penelitian ini selaras dengan hasil penelitian kami sebelumnya yang memperlihatkan bahwa ekstrak non polar<smiles>CC(=O)OC1C[C@](C)(O)C(=C=C=C(C)C=CC=C(C)C=CC=CC=C(C)C=CC=C(C)C(=O)CC23O[C@]2(C)CC(O)CC3(C)C)[C@@](C)(O)C1</smiles>

Gambar 6. Struktur molekul fukosantin (Peng et al., 2012).

Figure 6. Molecular structure of fucoxanthin (Peng et al., 2012). 
T. decurrens memiliki aktivitas sitotoksik terhadap sel HeLa. Efek sitotosik tersebut terjadi melalui mekanisme induksi apoptosis (Nursid et al., 2007). Ekstrak etil asetat $T$. decurrens juga mampu meningkatkan proliferasi sel-sel limfosit (Fajarningsih et al., 2008). Kemungkinan besar terdapat senyawa aktif selain fukosantin dalam ekstrak $T$. decurrens. Oleh karena itu diperlukan penelitian untuk mengetahui secara pasti senyawa aktif yang bertanggung jawab terhadap bioaktivitas antitumor pada T. decurrens.

Fukosantin merupakan senyawa karotenoid yang termasuk dalam golongan santofil. Perbedaan utama antara fukosantin dengan senyawa karotenoid lainnya adalah kehadiran ikatan allenic, monoepoksida, dua gugus hidroksil, gugus karbonil, dan gugus asetil di ujung cincin fukosantin (Gambar 6). Ikatan allenic bertanggung jawab terhadap aktivitas antioksidan dari fukosantin (Peng et al., 2011; Fung, 2012).

Kandungan fukosantin dilaporkan bervariasi secara signifikan dengan musim dan siklus hidup rumput laut, memuncak antara musim dingin dan musim semi (fase dewasa sporofit) dan terendah selama musim panas (fase penuaan) (Terasaki et al., 2009). Studi mengenai kuantifikasi fukosantin pada rumput laut liar dan budidaya masih terbatas hingga kini.

Karena sifat antioksidan yang kuat, fukosantin memiliki khasiat yang sangat baik sebagai antitumor. Meskipun demikian, terdapat kemungkinan bahwa fukosantin bekerja secara spesifik terhadap tipe sel tertentu dan menghambat proliferasi sel tumor melalui beberapa mekanisme. Menurut Wang et al. (2012), efek antitumor fukosantin terjadi melalui up-regulation protein p21WAF1/Cip 1 dan ROS pada jalur bcl-xl dan melalui down-regulation siklin-D. Mekanisme antitumor fukosantin juga berhubungan dengan protein GASS45, p38 MAPK atau SAPK/JNK. Fukosantin juga menginduksi siklus sel pada fase $G_{2} / M$ dan apoptosis pada sel kanker lambung MGC-803. Fukosantin menginduksi proses apoptosis pada sel leukemia HL-60. Pada sel ini, fukosantin menyebabkan pemecahan procaspase-3 dan poly (ADP-ribose) polimerase tanpa menimbulkan efek terhadap level protein $\mathrm{Bcl}-2$ dan $\mathrm{Bcl}-\mathrm{X}_{\mathrm{L}}$ atau Bax. Induksi apoptosis fukosantin pada sel HL-60 kemungkinan melalui permeabilisasi membran mitokondria dan aktivasi caspase-3 (Nara et al., 2004). Fukosantin juga menghambat proliferasi sel kanker kolon $\mathrm{HepG}_{2}$ melalui penghambatan siklus sel (Das et al., 2008). Yoshiko \& Hoyoku (2008) juga melaporkan induksi penghambatan siklus sel pada fase G1 (G1 arrest) pada sel HepG. Mekanisme antiproliferasi sel oleh fukosantin juga diamati oleh Sugawara et al. (2006) melalui penghambatan pembuluh darah baru (antiangiogenesis). Selain sebagai antioksidan dan antikanker, fukosantin juga menunjukkan aktivitas antihipertensi (Tierney et al., 2010), antiinflamasi (Heo et al. , 2010) dan antiobesitas (Maeda et al. , 2007).

Mengingat tingginya kelimpahan rumput laut coklat di Indonesia, dapat dinyatakan bahwa rumput laut coklat khususnya yang mengandung fukosantin tinggi memiliki potensi yang besar untuk dikembangkan sebagai agen antioksidan dan kemopreventif baik dalam bentuk herbal terstandar ataupun dalam bentuk fitofarmaka.

\section{KESIMPULAN}

Rumput laut coklat yang memiliki aktivitas antioksidan terbaik adalah $P$. australis diikuti oleh $H$. triquetra dan $T$. decurrens dengan nilai hambatan terhadap radikal bebas DPPH berturut-turut sebesar $53 \%, 45 \%$, dan 33\% pada dosis $50 \mu \mathrm{g} / \mathrm{ml}$. Rumput laut coklat dengan aktivitas sitotoksik terbaik adalah T. decurrens dengan nilai hambatan terhadap sel HeLa dan T47D sebesar 33\% dan 56\%. Kadar fukosantin tertinggi terdapat pada $H$. triquetra sebesar $88,5 \mathrm{mg}$ per $1 \mathrm{~g}$ ekstrak kasar etil asetat $(\mathrm{mg} / \mathrm{g})$ diikuti oleh $T$. decurrens $(86,9 \mathrm{mg} / \mathrm{g})$ dan $P$. australis $(77,8$ $\mathrm{mg} / \mathrm{g}$ ). Hasil penelitian menunjukkan bahwa terdapat korelasi yang nyata antara kandungan fukosantin dengan aktivitas antioksidan tetapi kandungan fukosantin tidak berkorelasi dengan aktivitas sitotoksik. Dengan mempertimbangkan bioaktivitas yang baik dan kandungan fukosantin yang tinggi, rumput laut coklat memiliki potensi yang besar untuk dikembangkan sebagai bahan baku untuk herbal terstandar ataupun fitofarmaka.

\section{DAFTAR PUSTAKA}

Anonim. 2012. Garis pantai Indonesia. http:// www. pantai.org/others/garis-pantai-indonesia. Diakses tanggal 3 Oktober 2012.

Budhiyanti, S.A., Raharjo, Marseno, D.W., and Lelana,Y.B. 2012. Antioxidant activity of brown algae Sargassum species extract from the coastline of Java Island. American Journal of Agricultural and Biological Sciences. 7(3): 337-346.

Buettner, G.R. 2009. What are free radicals? Sunrise Free Radical School $16^{\text {th }}$ Annual meeting of SFRBM, November, 18-22, 2009. http://www.srfbm.org/frs/ buettner.pdf. Diakses tanggal 1 Oktober 2012.

Das, S.K., Hashimoto, T and Kanazawa, K. 2008. Growth inhibition of human hepatic carcinoma HepG2 cells by fucoxanthin is associated with down-regulation of cycklin D. Biochimica et Biophysica Acta. 1780(4): 743-749.

Demirel, Z., Yildirim, Z.D., Tuney, I., Kesici, K., and Sukatar, A. 2012. Biochemical analysis of some brown seaweeds from the Aegean Sea. Botanica Serbica. 36(2): 91-95. 
Doonan, F. and Cotter, T.G. 2008. Morphological assessment of apoptosis. Methods. 44: 200-204.

Elmore, S. 2007. Apoptosis: A Review of Programmed Cell Death. Toxicologic Pathology. 35: 495-516.

Fajarningsih, N.D., Nursid, M., Wikanta, T. dan Marraskuranto, E. 2008. Bioaktivitas Ekstrak Turbinaria decurrens sebagai Antitumor (HeLa dan T47D) serta efeknya terhadap Proliferasi limfosit. Jurnal Pascapanen dan Bioteknologi Kelautan dan Perikanan. 3(1): 21-28.

Freshney, R.I. 2005. Culture of Animal Cells. A Manual of Basic Technique, Fifth Edition. New Jersey: John Wiley and Son, Inc.

Fung, A.Y.C. 2012. The Fucoxanthin Content and Antioxidant Properties of Undaria pinnatifida from Marlborough Sound, New Zealand. Thesis. Auckland University of Technology University. $78 \mathrm{pp}$.

Gupta, S. and Abu-Ghannam, N. 2011. Bioactive potential and possible health effects of edible brown seaweeds. Trends in Food Science and Technology, 22: 315-326.

Halliwell, B. 1999. Antioxidant defence mechanisms: from the beginning to the end (of the beginning). Free Radic. Res. 31: 261-272.

Heo, S. J., Yoon, W. J., Kim, K. N., Ahn, G. N., Kang, S. M., Kang, D. H., and Jeon, Y. J. 2010. Evaluation of antiinflammatory effect of fucoxanthin isolated from brown algae in lipopolysaccharide-stimulated RAW 264.7 macrophages. Food and Chemical Toxicology, 48(8-9): 2045-2051.

Hi, S.W., Choong, P.Y., Woo, K.K., and Wong, C.L. 2010. Stability studies of fucoxanthin from Sargassum binderi. Australian Journal of Basic and Applied Sciences. 4(10): 4580-4584.

Jaswir, I., Noviendi, D., Salleh, H.M., Taher, M., and Miyashita. 2011. Isolation of fucoxanthin and fatty acids analysis of Padina australis and cytotoxic effect of fucoxanthin on human lung cancer (H1299) cell lines. African Journal of Biotechnology. 10(81): 18855-18862.

Kadi, A. 2004. Potensi rumput laut di beberapa perairan pantai di Indonesia. Oseana. 29 (4): 25-36.

Kelman, D., Posner, E.K., McDermid, K.J., Tabandera, N.K., Wright, P.R., and Wright, A.D. 2012. Antioxidant activity of Hawaiian marine algae. Mar. Drugs. 10: 403-416.

Kusumawati, R dan Murdinah. 2012. Potensi pemanfaatan rumput laut: biodiversitas di pantai Binuangeun. Prosiding Seminar Nasional Inovasi Teknologi. Balai Besar Litbang Pengolahan Produk dan Bioteknologi Kelautan dan Perikanan, Jakarta.

Li, Y., Li, X., Lee, U., Kang, J.S., Choi, H.D and Son, B.W. 2006. A new radical scavenging anthracene glycoside, asperflavin ribofuranoside, and polyketides from a marine isolate of the fungus Microsporum. Chem. Pharm. Bull. 54(6): 882-883.

Martin, K.H. 2006. Targeting apoptosis with dietary bioactive agents. Exp. Biol. Med. 231: 117-129.
Maeda, H., Hosokawa, M., Sashima, T., Funayama, K., \& Miyashita, K. 2007. Effect of medium-chain triacylglycerols on anti-obesity effect of fucoxanthin. Journal of Oleo Science. 56(12): 615-621.

Mori, K., Ooi, T., Hiraoka, M., Oka, N., Hamada, H., Tamura, M., and Kusumi, T. 2004. Fucoxanthin and Its Metabolites in Edible Brown Algae Cultivated in Deep Seawater. Mar. Drugs. 2: 63-72.

Mallick, N. and Mohn, F.H. 2000. Reactive oxygen species: Response of algal cells. J. Plant Physiol.,157: 183193.

Nara, K.E., Terasaki, M., and Nagao, A. 2005. Characterization of apoptosis induced by fucoxanthin in human promyelocytic leukemia cells. Biosci. Biotechnol. Biochem. 69: 224-227.

Nomura, T., Kikuchi, M., Kubodera, A., and Kawakami, Y. 1997. Proton-donative antioxidant activity of fucoxanthin with 1,1-diphenyl-2-picrylhydrazyl (DPPH). Biochem. Mol. Biol. Int. 42(2): 361-70.

Nursid, M., Fajarningsih, N.D., Januar, H.I., and Wikanta, T. 2007. Induksi apoptosis dan ekspresi Gen p53 dari ekstrak makroalga Turbinaria decurrens pada sel tumor HeLa. Jurnal Pascapanen dan Bioteknologi Kelautan dan Perikanan, 2(1): 55-62.

Nursid, M., Januar, H.I., and Chasanah, E. 2008. Purifikasi dan identifikasi senyawa antioksidan dari spons Aaptos sp. Jurnal Pascapanen dan Bioteknologi Kelautan dan Perikanan. 2(1): 55-62.

Peng, J., Yuan, J.P., Wu, C.F., and Wang, J.H. 2011. Fucoxanthin, a marine carotenoid present in brown seaweeds and diatoms: metabolism and bioactivities relevant to human health. Mar. Drugs. 9: 1806-1828.

Sheu, J.H., Wang, G.H., Sung, P.J., and Duh, CY. 1999. New cytotoxic oxygenated fucosterols from the brown alga Turbinaria conoides. J. Nat. Prod. 62(2): 224227.

Sugawara, T., Matsubara, K., Akagi, R., Mori, M., and Hirata, T. 2006. Antiangiogenic activity of brown algae fucoxanthin and its deacetylated product, fucoxanthinol. Journal of Agricultural and Food Chemistry. 54: 9805-9810.

Terasaki, M., Hirose, A., Narayan, B., Baba, Y., Kawagoe, C., Yasui, H., and Miyashita, K. 2009. Evaluation of recoverable functional lipid components of several brown seaweeds (Phaeophyta) from Japan with special reference to fucoxanthin and fucosterol contents. Journal of Phycology. 45(4): 974-980.

Tierney, M.S., Croft, A.K., and Hayes, M. 2010. A review of antihypertensive and antioxidant activities in macroalgae. Botanica Marina. 53(5): 387-408.

Urikura, I., Sugawara, T. and Hirata, W. 2011. Protective effect of fucoxanthin against UVB-induced skin photoaging in hairless mice. Biosci. Biotechnol. Biochem. 75(4): 757-760.

Wang, J., Chen, S., Xu, S., Xu, X., Ma, D., Hu, X., and Cao, X. 2012. In Vivo induction of apoptosis by fucoxanthin, a marine carotenoid, associated with down- 
regulating STAT3/EGFR signaling in sarcoma 180 (S180) xenografts-bearing mice. Mar.Drugs. 10: 2055-2068.

Windono, T. 2001. Uji peredaman radikal bebas terhadap 1,1-difenil-2-pikrilhidrazil (DPPH) dari ekstrak kulit buah dan biji anggur (Vitis vinifera L.). Probolinggo biru dan Bali. Artocarpus. 1(1): 34-43

Yoshiko, S and Hoyoku, N. 2007. Fucoxanthin, a Natural Carotenoid, Induces G1 Arrest and GADD45 Gene
Expression in Human Cancer Cells. In Vivo. 21: 305 -310 .

Yoo, M.S., Shin, J.S., Choi, H.E., Cho, Y.W., Bang, M.H., Baek, N.I and Lee, K.T. 2012. Fucosterol isolated from Undaria pinnatifida inhibits lipopolysaccharideinduced production of nitric oxide and proinflammatory cytokines via the inactivation of nuclear factor-êB and p38 mitogen-activated protein kinase in RAW264.7 macrophages. Food Chemistry. 135(3): 967-975. 
